\title{
JUURNAL_RU
}

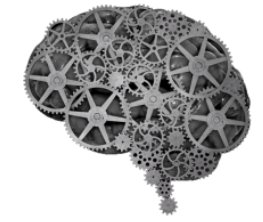

COMPANY GROUP "INTELLEKT"

\author{
Хрунина Н. П. \\ Институт горного дела Дальневосточного отделения \\ Российской академии наук \\ Хабаровск, Россия
}

doi: 10.18411/lj2016-3-42

\section{Исследование процесса микродезинтеграции минеральной составляющей гидросмеси}

Повышение полноты извлечения полезных ископаемых из недр ставит перед исследователями важную задачу, решение которой позволит на стадии обогащения россыпей осуществить разрушение минеральной составляющей с минимальным уровнем потерь золота и других ценных компонентов. Значительную роль в решении этой проблемы может сыграть развитие эффективных и безопасных процессов, основанных на новых физических принципах воздействия на пески и их гидросмеси [1-2]. В настоящее время получили развитие резонансные, электротермические, акустические, теплофизические, гидродинамические эффекты разрушения минеральной составляющей, моделируемые в сильных электрических полях мощных ускорителей, ультразвуковых, электроразрядных, электромагнитных, лазерных, вибрационных, гидродинамических воздействий.

Анализ данных, полученных в результате исследования дезинтегрированной посредством ультразвука минеральной составляющей гидросмесей на седиментационную устойчивость в воде, позволил оценить эффективность процесса и выявить оптимальные рабочие параметры исследования, рис. 1-2. Установлены рациональные параметры обработки при 
частоте излучения ультразвука 20 кГц: время - от 5 до 15 минут; интенсивность от 2 до $10 \mathrm{BT} / \mathrm{cm}^{2}$.

Изменения удельной межфазной поверхности минеральных частиц гидросмеси после механической активации и ультразвуковой обработки при интенсивности ультразвука $5 \mathrm{~B} / \mathrm{cm}^{2}$ и временном интервале 5, 10, 15 минут представлены на гистограмме рис. 2. Контрольным параметром являлась удельная поверхность, которая контролировалась с помощью установки Laser Particle Sizer “Analysette 22”. Увеличение удельной поверхности частиц при ультразвуковой обработке происходит в 3-5 раз по сравнению с механической обработкой [1].

Полученные данные дают возможность на основе предварительной оценки процесса определить эффективные параметры энергетического воздействия на систему для выявления и подтверждения основных физических зависимостей, позволяющих управлять процессом. На основе данных, полученных с помощью автоматического гранулометрического экспресс-анализа на установке Laser Particle Sizer “Analysette 22”, гистограмм фазового распределения частиц в исходном состоянии после механического воздействия и ультразвуковой обработки, а также других характеристик дезинтеграции, составлена более наглядная картина эффективности процесса, как механического инициирования, так и ультразвукового воздействия.

Сравнение изменений фракционного состава, полученных при различных временных интервалах, дает представление о количественном изменении частиц в объеме исследуемого состава гидросмеси. При интенсивности излучения 10 $\mathrm{BT} / \mathrm{cm}^{2}$ и времени обработки 10 минут, в объеме массовой доли дезинтегрированной слабопластичной минеральной составляющей, равной 55\%, размер частиц уменьшился в среднем в 2 раза, а в объеме массовой доли, равной $90 \%$, он достигает этого уровня при времени 15 минут.

На основе проведенных исследований разработан способ направленного изменения свойств горной породы посредством СВЧ-термомеханического, 
ультразвукового и гравитационно-аэродинамического воздействий и геотехнологический комплекс с многоступенчатой дезинтеграцией [3-4]. Использование, предложенного в качестве оценочного параметра, условного коэффициента трансформации позволило разработать способ контроля энергетических параметров ультразвукового излучения [5].

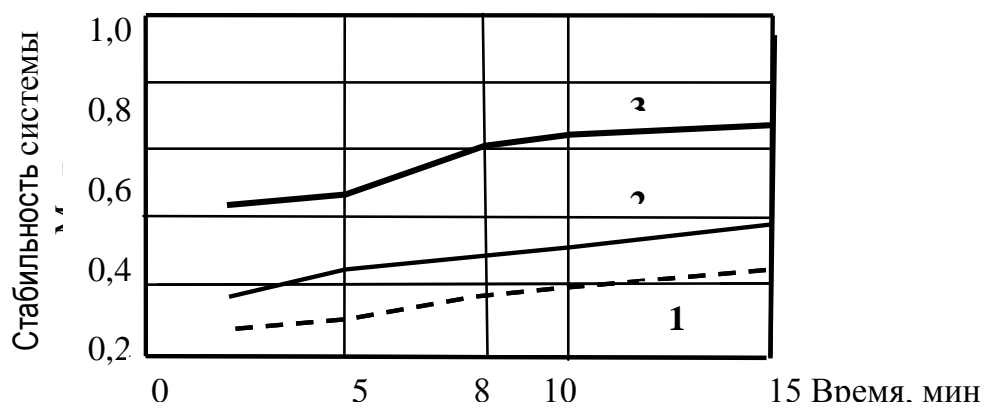

Рис. 1. График седиментационной устойчивости минеральной составляющей гидросмеси: $1,2,3$ - при интенсивности излучения $2 ; 5 ; 10 \mathrm{BT} / \mathrm{cm}^{2}$

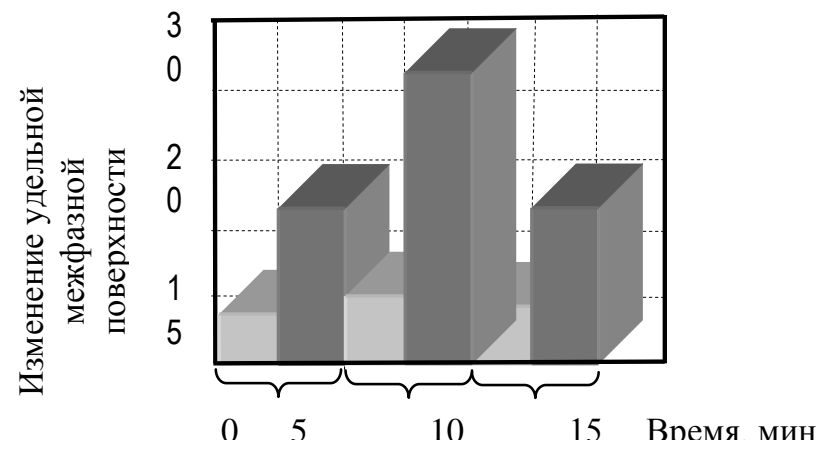

Рис. 2. Гистограмма изменения удельной межфазной поверхности частиц минеральной гидросмеси после механического и ультразвукового воздействий при интенсивности излучения 5 Вт/см ${ }^{2}$ - после механического воздействия; - после воздействия ультразвуком

На основе проведенных исследований разработан способ направленного изменения свойств горной породы посредством СВЧ-термомеханического, ультразвукового и гравитационно-аэродинамического воздействий и геотехнологический комплекс с многоступенчатой дезинтеграцией [3-4]. Использование, предложенного в качестве оценочного параметра, условного коэффициента трансформации позволило разработать способ контроля энергетических параметров ультразвукового излучения [5].

Полученные в результате экспериментальных исследований эффекты уточняют представления о механизме дезинтеграции с использованием ультразвука.. 


\section{Литература:}

1. Хрунина Н.П.и др. Новые аспекты научных основ ультразвуковой дезинтеграции высокоглинистых золотосодержащих песков россыпей Приамурья - Хабаровск: Изд-во Тихоокеан. гос. ун-та, 2011. - 155 с. ISBN 978-5-7389-1030-2.

2. Хрунина Н.П., Чебан А.Ю. Оценка влияния водонасыщения на дезинтеграцию высокоглинистых песков при разработке россыпей благородных металлов // Вестник Магнитогорского государственного технического университета им. Г.И. Носова. 2015. №4. С. 50-55.

3. Пат. РФ №2264869. Способ направленного изменения свойств горной породы посредством СВЧ-термомеханического, ультразвукового и гравитационно-аэродинамического воздействий / Н.П. Хрунина, О.В. Стратечук и др. // опубл. 27.11.2005, Бюл. № 33.

4. Пат. РФ.2209678. Геотехнологический комплекс с многоступенчатой дезинтеграцией / Н.П. Хрунина, О.В. Стратечук и др. // опубл. 10.08.2003, Бюл. № 22.

5. Пат. РФ №2276727 РФ. Способ управления процессом трансформации золотосодержащей породы / Н.П. Хрунина, О.В. Стратечук и др. // опубл. 20.05.2006, Бюл. №14. 